$12-31-2020$

\title{
Citizen participation in times of crisis: Understanding participatory budget during the COVID-19 pandemic in Nepal
}

Thaneshwar Bhusal

Institute of Governance and Policy Analysis, University of Canberra, Australia, tsbhusal@gmail.com

Follow this and additional works at: https://scholarhub.ui.ac.id/ajce

Part of the Public Administration Commons, Public Policy Commons, Urban Studies Commons, and the Urban Studies and Planning Commons

\section{Recommended Citation}

Bhusal, Thaneshwar (2020). Citizen participation in times of crisis: Understanding participatory budget during the COVID-19 pandemic in Nepal. ASEAN Journal of Community Engagement, 4(2), 321-341. Available at: https://doi.org/10.7454/ajce.v4i2.1103

Creative Commons License (c) (i) ()

This work is licensed under a Creative Commons Attribution-Share Alike 4.0 License.

This Research Article is brought to you for free and open access by the Universitas Indonesia at ASEAN Journal of Community Engagement. It has been accepted for inclusion in ASEAN Journal of Community Engagement. 


\title{
Citizen participation in times of crisis: Understanding participatory budget during the COVID-19 pandemic in Nepal
}

\author{
Thaneshwar Bhusal ${ }^{*}$ \\ aInstitute of Governance and Policy Analysis, University of Canberra, Australia
}

Received: September 7th, 2020 || Revised: November 21 $1^{\text {st }}, 2020$ || Accepted: December 26 $6^{\text {th }}, 2020$

\begin{abstract}
This research assumes that various forms and scales of lockdowns and social distancing measures have limited local decision-makers' ability to reach out to communities as part of their mandatory annual participatory budgeting processes. Building upon this proposition, this article assesses Nepal's local budgeting process of 2020 to understand the degree to which it succeeded (or failed) in incorporating citizen's voices in the annual handbook of local public policies and budgets. The research followed a qualitative case study research methodology. It generated interviews with participants including ordinary people, local politicians, and bureaucrats from 20 different municipalities and a federal ministry in Nepal. Other textual data (official publications, field notes and observational scripts) provided complementary evidence to answer the research questions. Findings suggest that the coronavirus pandemic has played significant roles in limiting ordinary people's democratic right to participate in local decisionmaking yet flaws in institutional design and unpredictable mayoral power contributed to delaying the annual budget approval process. The research contributes to the literature on participatory governance in developing countries, with some practical suggestions to increase citizen engagement chances in times of crisis.
\end{abstract}

Keywords: Nepal; participatory governance; Coronavirus; pandemic; participatory budgeting.

\section{Introduction}

By the second week of July every year, all local governments in Nepal must approve their annual local budgets, policies, and programs. The Local Governance Act (2017) ensures that this timeline consistently hews to annual federal (last week of May) and provincial (third week of June) budget-making deadlines. The purpose of such a timebound budgeting process is said to be necessary to assure policy and budgetary harmonization across all three levels of government: federal, provincial, and local. Not all local governments, however, can meet this timeline, irrespective of the participatory planning schedule, an annual budgetary and policymaking process that runs through 6 months of long yet linear activities. Failure to meet on-time approval of annual budgets means inter alia suspension of federal and provincial grants.

The Local Governance and Community Development Program in 2019 suggest empirical evidence that there does not seem to be any single reason why some local governments succeed

\footnotetext{
*Corresponding Author: thaneshwar.bhusal@canberra.edu.au / tsbhusal@gmail.com
} 
Thaneshwar Bhusal | ASEAN Journal of Community Engagement | Volume 4, Number 2, 2020

in approving their annual budgets before the deadline while others fail to do so. One reason that has been cited is "...an obligation to go to communities with consultative and deliberative forums..." that takes several months (Pandeya \& Shrestha, 2016). In some municipalities, local politicians tend to create conflicts and tensions during the annual policymaking and budgeting process, with the hope of making consensual decisions (Byrne \& Shrestha, 2014). In others, local public administrators contribute to delaying the process, partly because of their inability to balance voices of citizens with municipal policy guidelines. Exceptional circumstances such as the prevalence of the coronavirus (COVID-19) pandemic appear to explain why and to what extent local governments are unable to meet the deadline to approve their annual budgets formally, systematically, and legally.

This paper presents an assessment of Nepal's local 2020 budgeting process across 20 municipalities with an aim to understand the degree to which municipalities succeeded (or failed) to meet their annual deadlines of participatory policymaking and budgetary processes. Special emphasis has been given to the COVID-19-induced pandemic context, which-as in other countries-appeared as a national public health threat to Nepal in early March 2020, triggering federal, provincial, and local governments to come up with ruthless measures such as the lockdown. The proposition of this research, therefore, is that various forms and scales of lockdowns, coupled with new norms of social distancing, have cruelly limited the ability of decision-makers to reach out to communities as part of their mandatory annual participatory budgeting processes in Nepal. Perceiving this unprecedented public health crisis through a narrow lens suggests that decision-makers took lockdowns and social distancing as pretext to dodge participatory channels to make annual local budgets. However, this cannot be generalized. Viewing the COVID-19 crisis from broad perspectives enlightens us with several democratic, administrative, and technocratic insights-though fairly limited in number-at several local government jurisdictions that genuinely include citizens' views on annual local budgets (Yeni, Najmah, \& Davies, 2020). Nevertheless, we lack plausible literature to justify or falsify both scenarios.

There are five sections in this paper. After this introduction, a brief literature review is conducted to understand how local policymaking and budgeting processes in the times of crisis are conceptualized in the normative and empirical literature. This exercise is expected to help us outline an analytical framework to guide this research through data collection to interpretation. The third section briefly outlines the research methodology. This section also describes Nepal's annual budgetary process in municipalities as a case study. The fourth section 
Thaneshwar Bhusal | ASEAN Journal of Community Engagement | Volume 4, Number 2, 2020

moves on to explain findings on how Nepal's usual annual participatory policymaking and budgeting process has shifted through the ongoing COVID-19 pandemic. The discussions presented in this section help the academic and praxis community to understand how the pandemic has adversely impacted people's democratic right to participate in local decisionmaking. The final section summarizes the research findings by drawing broader scholarly and practical implications of this most unfortunate time of pandemic on citizen engagement.

\subsection{Locating the study in the literature}

This research recognizes that there is a challenge to exhume participatory governance literature that informs how decision-makers with participatory thirst cope with public health crises such as COVID-19. As informed by scholars from diverse academic backgrounds, the quality of participatory governance in both advanced and developing countries has deteriorated due to the COVID-19 crisis, which-in a way-had already been battling to cope with the institutional malaises of representative decision-making settings (Boin et al., 2020). Although the impact of COVID-19 on the theoretical literature of participatory decision-making is still in its infancy, empirical evidence generated in other crisis contexts suggests that decision-makers in the time of crisis seek for legislative, administrative, and technical loopholes to avoid or prevent ordinary citizens from participating in the decision-making processes (Curato, Sass, Ercan, \& Neymer, 2020). We are thus forced to imagine that public health crises and natural disasters do not generally provide favourable environments for participatory governance.

In absence of definitive scholarly insights on the impact of COVID-19 on participatory governance, scholars seem to have reoriented themselves toward, if not relied upon, other disciplines such as public health and natural resource management. This is not a new practice. The participatory governance literature has greatly benefited as a cross-cutting field of study that brings both theoretical insights and empirical evidence from diverse academic disciplines such as development economics (Heller \& Rao, 2015), democracy studies (Elstub, 2018), policy studies (Waheduzzaman \& As-Saber, 2015), and even public health (Murphy, Callaghan, \& Longino, 1995). Each of these fields provides unique theoretical and empirical insights into how participatory governance is practiced in different political and economic contexts. The overarching aim of the practice of participatory governance in developing countries has been claimed to bring good governance, by ensuring citizen participation in decision-making (Yasay, 2018). 
Thaneshwar Bhusal | ASEAN Journal of Community Engagement | Volume 4, Number 2, 2020

The digital governance scholarship is perhaps the most cited academic field of study 'citiezn engagement' during the current COVID-19 crisis. Following the outbreak of the virus, governments across the globe started to invest huge amounts of money in the development and enhancement of their online portals, primarily with the aim of providing participatory platforms for ordinary people. Often labelled as digital participation (Gilman \& Peixoto, 2019), the COVID-19 scenario seems to be shadowing the importance of face-to-face deliberation in small-scale fringe policy issues, which are mostly formulated by local governments. While digital participation will certainly offer convenient avenues for citizens with competent levels of digital literacy to participate in local decision-making, people with digital illiteracy will see themselves as being excluded from such democratic exercises. Institutions and processes of participatory decision-making, therefore, will be required to remodel in a way that both online and offline participation work side-by-side.

The political science and policy studies literature seems to understand the more in-depth implications of the COVID-19 on broader polity, politics, and policy apparatuses at different levels of government. New concepts like i-voting have already started to float in the election studies even in the developing world, which will certainly reshape our understanding of representative democracy (Agbesi, 2020). Following new norms of social distancing, the concept of i-voting will certainly help citizens to avoid queuing on election days, yet the significance of such "clicktivism" to the practice of democracy is unclear (Halupka, 2014). Similarly, public policy scholarship seems to be attentive to understanding how quickly and effective the government's response was in identifying the possible economic, social, and political damage the COVID-19 could cause (Capano, et al., 2020).

This is not a new problem though. Scholars have already piled up diverse empirical evidence from across the world that the COVID-19 has adversely impacted many participatory policymaking and budgetary processes (Moon, 2020). One way of looking at how citizen engagement programs were impacted by the COVID-19 is to see different contexts across different jurisdictions experiencing diverse challenges. Drawing from the crisis management scholarship, we can categorize such challenges in terms of policy reassessment, accountability, and learning (Boin, Stern, \& Sundelius, 2016). The notion of policy reassessment indicates that several jurisdictions need to reassess their citizen engagement policies considering the damage caused by the pandemic. Accountability challenges refer to why local officials chose certain local policies while ignoring others. And learning means devising a post-pandemic 
Thaneshwar Bhusal | ASEAN Journal of Community Engagement | Volume 4, Number 2, 2020

participatory environment in which citizens of diverse identities and skills will feel free to engage with local officials to make decisions.

The ambiguity of knowledge about the significance of the COVID-19 pandemic on citizen engagement thus requires us to devise context-specific analytical frameworks. We do not know what policy approach works best for citizens to participate in the making of local public policies in times of crisis. Some governments seem to have successfully controlled the spread of the virus; yet there is less empirical evidence on how citizens are participating in the decisionmaking that affects them the most (Halligan, 2020).

\section{Methods}

The research was designed as a qualitative case study with interpretive perspectives on analysis. The fundamental source of information was a dedicated website maintained by the Ministry of Federal Affairs and General Administration (MoFAGA), a federal government entity that holds the right to coordinate local governments with federal and provincial governments in Nepal (Ministry of Federal Affairs and General Administration, 2020). In all, 10 successful municipalities, along with a further 10 unsuccessful municipalities, were contacted via telephone to understand what factor(s) contributed to their meeting, or not meeting, the annual budgeting deadlines. The detail of these municipalities is listed on Table 1.

Table 1. Ten successful and ten failed municipalities

\begin{tabular}{|c|c|c|}
\hline Province & Failed Municipalities & Successful Municipalities \\
\hline \multirow[t]{2}{*}{ Province 1} & $\begin{array}{l}\text { Menchhyoyam Rural } \\
\text { Municipality, Terhathum }\end{array}$ & Ilam Municipality, Ilam \\
\hline & $\begin{array}{l}\text { Budhiganga Rural } \\
\text { Municipality, Morang }\end{array}$ & Triyuga Municipality, Udayapur \\
\hline \multirow[t]{2}{*}{ Province 2} & Mirchaiya Municipality, Siraha & Siraha Municipality, Siraha \\
\hline & Rajdevi Municipality, Rautahat & Nijgadh Municipality, Bara \\
\hline \multirow{2}{*}{$\begin{array}{l}\text { Bagmati } \\
\text { Province }\end{array}$} & Kakani Municipality, Nuwakot & Bidur Municipality, Nuwakot \\
\hline & $\begin{array}{l}\text { Dakshinkali Municipality, } \\
\text { Kathmandu }\end{array}$ & Rapti Municipality, Chitwan \\
\hline $\begin{array}{l}\text { Gandaki } \\
\text { Province }\end{array}$ & $\begin{array}{l}\text { Gandaki Rural Municipality, } \\
\text { Gorkha }\end{array}$ & Byas Municipality, Tanahu \\
\hline $\begin{array}{l}\text { Lumbini } \\
\text { Province }\end{array}$ & $\begin{array}{l}\text { Suddodan Rural Municipality, } \\
\text { Kapilvastu }\end{array}$ & $\begin{array}{l}\text { Butwal Sub-metropolitan city, } \\
\text { Rupandehi }\end{array}$ \\
\hline
\end{tabular}


Thaneshwar Bhusal | ASEAN Journal of Community Engagement | Volume 4, Number 2, 2020

\begin{tabular}{lll}
\hline Province & Failed Municipalities & Successful Municipalities \\
\hline Karnali & Mahabai Rural Municipality, & Narayan Municipality, Dailekh \\
Province & Kalikot & \\
$\begin{array}{l}\text { Far-western } \\
\text { Province }\end{array}$ & Patan Municipality, Baitadi & Godawari Municipality, Kailali \\
\hline
\end{tabular}

Source: Ministry of Federal Affairs and General Administration (2020)

A total of twenty-five interviews were conducted without adopting a systematic approach of any participant selection method. During the field works in selected municipalities (three successful viz. Butwal, Bidur and Byas and two failed viz. Dakshinkali and Suddodhan), potential interviewees were pointed out by local officials who were responsible for organising the annual budget and policy process in the concerned municipalities. The interviewees include officials working at the Ministry of Federal Affairs and General Administration (2), mayors/deputy mayors (7), administrative officers (10) and ordinary people (6) in the twenty selected municipalities, representing at least one individual from one municipality. A set of semi-structured interview questions was developed to inquire how ordinary people were offered by municipal authorities in case study local governments to participate in the making of 2020/21 annual policy and budgetary process.

The research is aware of the limitations of case study research (Campbell \& Yin, 2018). It, therefore, carefully draws findings and systematically interprets them. In the absence of comprehensive firsthand data, the research does not aim to compare successful and failed municipalities, yet it brings comparative insights from interviewees based on the predefined set of semi-structured questions.

\subsection{Description of the case}

The use of participatory governance in Nepal has variously waxed and waned in the last seven decades. Starting from the early years of the 1950s, diverse forms of community engagement programs were introduced with the hope of offering participatory avenues for ordinary citizens. Bhusal (2018) notes that the earliest efforts at participatory local governance in Nepal were not sufficient to genuinely incorporate ordinary people's voice in local governance. Instead, local elites-entrusted by the then-dynasties-would facilitate, if not dominate, the entire local policy and budgeting process. Khadka (1986) asserts that local 
Thaneshwar Bhusal | ASEAN Journal of Community Engagement | Volume 4, Number 2, 2020

institutions of earlier times in Nepal were not empowered to exercise autonomy in making local public policy but were instead advised to implement policies formulated in the centre.

After the reintroduction of parliamentary democracy in 1990, local governance reforms took fast-track routes to offer participation opportunities to ordinary people in local decisionmaking. Several institutions and processes of local decision-making were reframed in accordance with the constitution of the kingdom of Nepal, which aimed at inter alia deepening democracy at the local level (Ministry of Local Development, 2003). Although several subsequent fringe reforms contributed to gradually strengthening the notion of participatory local governance in the country, the modern-day participatory institutions at the local level are the results of robust constitutional reforms conducted after the early years of the 2000s (Government of Nepal, 2007; 2015; 2017).

Under the new federalist Constitution, local governments in Nepal must undergo a participatory process to formulate their short- and mid-term local public policies and annual budgets. In principle and under the prevailing legislation of local governments, they are empowered to raise revenues and taxes, amend ongoing budgetary arrangements, and thus implement their local public policies and budgets only by gaining approval from their councils (or, Sabha). The institutional design of local governments has thus been designed in a way that they can practically articulate ordinary peoples' voices in annual local public policies and budgets.

The annual planning and budgeting process are implemented in a specified timeframe, consisting of nine sequential activities (Figure 1). Most of these activities are operationalized in a way that municipal authorities provide policy guidelines and budgetary ceilings as topdown tools whereas ordinary citizens of different types inject community voices as bottom-up contents (Ministry of Federal Affairs and General Administration, 2017). Additionally, the overall implementation of the annual planning and budgeting process inherits several of the federal and provincial policy guidelines across a range of policy areas and also for line-item budgets (National Planning Commission, 2018).

The annual planning and budgetary process commences in February every year. The first phase of the process involves three interrelated activities: (i) estimated gross income and expenditure of the next fiscal year (by municipalities); (ii) obtain tentative figures of shared revenue ceilings from provincial and federal governments; and (iii) assign specific policy sectors to elected municipal members for organising consultative and deliberative forums across communities. The second phase focuses on conducting two major technical tasks of the 
annual planning and budgeting process. The first task is to form a local revenue advisory committee (led by the vice-chair or deputy mayor) mandating the exploration of new areas of revenue generation as well as the revision of existing ones. The second task is to establish a budget committee (led by the mayor or chairperson) with the aim of creating a balanced macroeconomic framework of the concerned municipality. Once these pre-budgeting activities are conducted, municipalities are required to organize consultative and deliberative forums across a range of geographical locations-mostly through sub-municipal entities known as ward committees and or community-based organizations. The overarching aim of such forums is to ensure the wider participation of ordinary people in the annual policy and budgeting process.

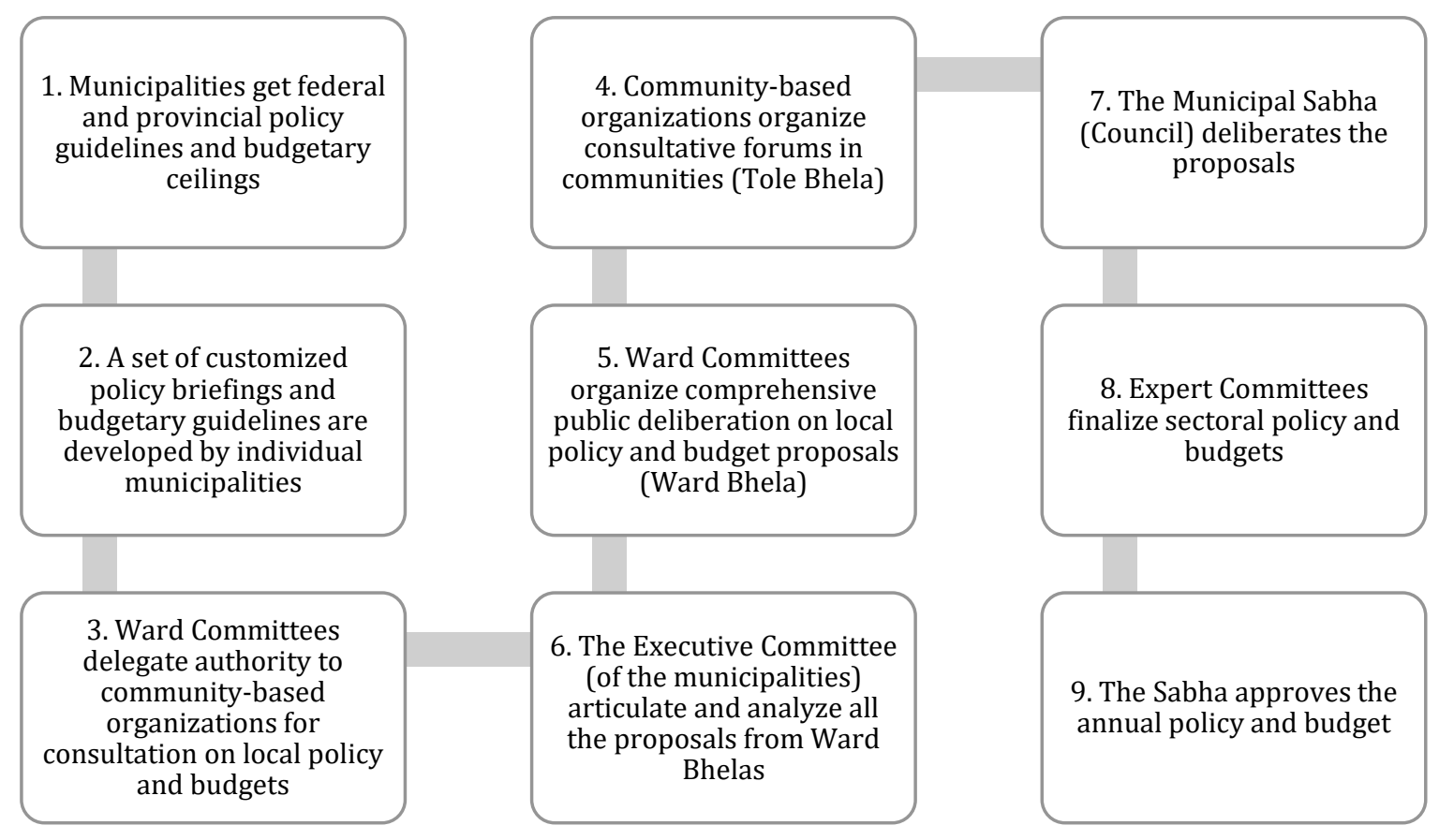

Fg. 1 Annual local planning and budgeting process

Source: Adapted from Planning and Budgeting Guidelines for Local Governments in 2017 and 2018

The final phase commences in June. Municipalities are expected to collect all the proposals forwarded through the Ward Committees. The executive board of municipalities then analyses all the proposals against the policy guidelines and budgetary ceilings. Further deliberationsthough not legally required-are also found to be organized in some case study municipalities. The primary concern of such deliberations or analyses is to scrutinize all the proposals against the policy guidelines and budgetary ceilings. Tensions and conflicts obviously emerge among both elected leaders and unelected local politicians while producing a list of policy and budgetary recommendations, yet such circumstances are technocratically handled by the 
Thaneshwar Bhusal | ASEAN Journal of Community Engagement | Volume 4, Number 2, 2020

adoption of a set of project prioritization criteria (Ministry of Federal Affairs and General Administration, 2017).

These criteria are prescribed by the Ministry of Federal Affairs and General Administration to make sure that all local governments in Nepal formulate their annual local public policies and budgets consistently with federal and provincial policy and budgetary frameworks (Ministry of Federal Affairs and General Administration, 2017). While the adoption of such criteria into their project selection and prioritization exercise helps local governments to systematically channel their available resources, critics of local autonomy argue that providing project selection and prioritization criteria by the federal government is a clear breach of constitutional guarantees of local autonomy (Acharya \& Zafarullah, 2020). Nevertheless, the prevailing Local Government Act (Government of Nepal, 2017) empowers municipal councils (or Sabha) with ultimate authority to develop their own context-specific project selection and prioritization criteria. That said, this research did not find any empirical evidence of the complete adoption of such criteria in the case study of municipalities.

\section{Results and Discussion}

The research acknowledges that Nepali local governments under the federal constitution enjoy unprecedented power and resources. However, such privilege was unfortunately found to be underestimated by many failed municipalities, particularly in reaching the deadline to approve their annual budgets. Table 1 below brings comparative statistics of all the 753 local governments in terms of their status on budget approval during the fiscal years of 2019-2020 and 2020-2021. At the outset, the data shows that the number of failed municipalities were only 20 (or $2.7 \%$ ) in 2019, whereas the number of failed municipalities rose to 109 (or $13.95 \%$ ) in 2020. At the core, the COVID-19 pandemic seems to have played a key role in delaying the approval of the annual policymaking and budgetary process. Still, several other factors remain in the background of each municipality as contributing factors to delays of their budget approval processes. 
Thaneshwar Bhusal | ASEAN Journal of Community Engagement | Volume 4, Number 2, 2020

Table 1. Statistics of annual policymaking and budgeting in municipalities

\begin{tabular}{|c|c|c|c|c|c|c|c|}
\hline \multirow[t]{2}{*}{ Province } & \multirow{2}{*}{$\begin{array}{l}\text { Number of } \\
\text { local } \\
\text { governments }\end{array}$} & \multicolumn{3}{|c|}{$\begin{array}{c}\text { Statistics of on-time budget } \\
\text { approval in } 2019\end{array}$} & \multicolumn{3}{|c|}{$\begin{array}{l}\text { Statistics of on-time budget } \\
\text { approval in } 2020\end{array}$} \\
\hline & & $\begin{array}{l}\text { On } \\
\text { time }\end{array}$ & Delayed & $\begin{array}{l}\text { Failed } \\
\text { percentage }\end{array}$ & $\begin{array}{l}\text { On } \\
\text { time }\end{array}$ & Delayed & $\begin{array}{l}\text { Failed } \\
\text { percentage }\end{array}$ \\
\hline Province 1 & 137 & 137 & 0 & $0.0 \%$ & 125 & 12 & $8.8 \%$ \\
\hline Province 2 & 136 & 117 & 19 & $14.0 \%$ & 85 & 51 & $37.5 \%$ \\
\hline $\begin{array}{l}\text { Bagmati } \\
\text { Province }\end{array}$ & 119 & 118 & 1 & $0.8 \%$ & 108 & 11 & $9.2 \%$ \\
\hline $\begin{array}{l}\text { Gandaki } \\
\text { Province }\end{array}$ & 85 & 85 & 0 & $0.0 \%$ & 77 & 8 & $9.4 \%$ \\
\hline $\begin{array}{l}\text { Lumbini } \\
\text { Province }\end{array}$ & 109 & 109 & 0 & $0.0 \%$ & 105 & 4 & $3.7 \%$ \\
\hline $\begin{array}{l}\text { Karnali } \\
\text { Province }\end{array}$ & 79 & 79 & 0 & $0.0 \%$ & 75 & 4 & $5.1 \%$ \\
\hline $\begin{array}{l}\text { Far- } \\
\text { western }\end{array}$ & 88 & 78 & 0 & $0.0 \%$ & 73 & 15 & $17 \%$ \\
\hline Province & & & & & & & \\
\hline Total & 753 & 733 & 20 & $\begin{array}{l}2.7 \% \\
\text { (Average) }\end{array}$ & 648 & 105 & $\begin{array}{l}13.95 \% \\
\text { (Average) }\end{array}$ \\
\hline
\end{tabular}

Source: Ministry of Federal Affairs and General Administration (2020)

In-depth analysis of annual local budgeting process data suggests that there does not seem to be any general tendency to breach the deadline. Most municipalities were found to be completing their annual policymaking and budgeting process on time. Some municipalities try their best to accomplish the task on time, yet their internal political tensions and conflicts between the mayor and other elected members of the executive board contribute to lengthening the annual policy and budgetary approval process. Such tensions and conflicts between elected representatives were found to be ubiquitous, mostly in those municipalities represented by one political party, where most elected members were represented other political party/parties.

The comparative insights generated from Table 1 above shows a few important aspects of on-time budget and policy approval across municipalities, specifically in Province 2. There 
Thaneshwar Bhusal | ASEAN Journal of Community Engagement | Volume 4, Number 2, 2020

appeared to be evidence in this province that 19 municipalities had failed to achieve the budgetary deadline even before the pandemic emergency (i.e., in previous fiscal years) which rose to 51 during the 2020/21 local policymaking and budgetary process. Two key factors were identified from the interview transcripts about why local governments in Province 2 have been failing to achieve the budgetary deadline. First, the overall landscape of local governance in Province 2 is (re)shaped by informal political behaviour, despite the availability of the unprecedented scale of local autonomy provisioned in the 2015 constitution of Nepal. Many elected representatives in municipalities, including the mayors, were found to have been influenced by unelected political party leaders who obliged the elected leaders to, inter alia, rely upon political pressures to address their vested interests through annual policy and budgets.

The local public administrations can be analysed as a second factor behind the failure to achieve budgetary deadline in Province 2. Under the prevailing federalist constitution, local governments are empowered to have their own public administration systems, with some exceptions to comply with certain federal laws. However, this has not materialized, even 5 years since the implementation of the federalist constitution in Nepal. This has brought a chaotic local administrative system, resulting in (a) a shortage of local bureaucrats, (b) discontinuity of chief administrative officers deployed by the federal government, and (c) a lower level of administrative capacity to smoothly run the annual participatory policymaking and budgetary processes (Bhusal, 2019). The observational data prepared for this research confirms that these factors were less prevalent in relatively successful municipalities in other provinces (Pandeya \& Oyama, 2019). Specific to the research questions of this research, four key insights are discussed as significant findings.

\subsection{Design flaws persist in the annual local budgeting process}

The straightforward explanation of the existing institutional design of Nepal's annual local budgeting offers several insights into citizen engagement. On its strength, the institution, also known as the participatory budgeting process (Figure 1), showcases how ordinary people are given space across a range of steps in the budgeting cycle. The three different stages of the annual budgeting process offer varieties of participatory platforms in informal, semi-formal, and formal settings whereby people of different identities, interests, and capacities actively engage in exploring and prioritizing their developmental needs, policy priorities, and budgetary preferences (Bhusal, 2019). Ordinary people are given unrestricted spaces—though 
Thaneshwar Bhusal | ASEAN Journal of Community Engagement | Volume 4, Number 2, 2020

not in all aspects of the budgetary process in most of the deliberative forums of the annual policymaking and budgetary process across communities. However, there is a question of the degree to which such forums genuinely incorporate ordinary people's views on local budgeting (Pandeya \& Shrestha, 2016). When views expressed by ordinary people in participatory forums take a long time to analyse with the aim of incorporating them in the actual policy decisions, the entire policymaking and budget approval process gets delayed. In other words, taking time to analyse public input naturally delays the entire process, especially when the annual policy and budgetary process is expected to be completed within a given timeframe.

To its weakness, many of the activities appear to be ceremonial. The organizers of the participatory budgeting process simply fulfill the requirement to organize community-based consultations, offer deliberation opportunities to participants and thereafter prepare a list of what participants have said in such spaces. The database prepared for this research confirms that there seems to be no mechanism for ensuring that ordinary people's views are expressed across several steps of the participatory budgeting process and genuinely reflected in the actual decisions. In contrast, elected ward committee chairpersons at the lower-level forums dictate what they think are the priorities of their communities. No legislative arrangement can challenge the views of elected officials to replace their views with ordinary citizens' opinions.

The institutional design itself can be regarded as a cause to delay the annual budget approval process in municipalities. Although all three stages of this noble annual process provide avenues for ordinary people to have their say and negotiate with local officials, they take time, energy, and cost (Bhusal \& Pandeya, 2021). In the case study of municipalities - especially in failed ones, municipal officials were found to be taking a long time to finalize agendas for deliberation. Both elected and unelected politicians were having difficulties balancing their views on agendas. On the contrary, local bureaucrats were observed to be less energized to balance ordinary people's views with unelected politicians' opinions on several issues. Failure to have predefined agendas of discussions caused significant delays in hosting the communitybased consultations (Activity 4 in Figure 1 above). In the absence of prioritized lists of policy and budgetary demands produced by communities, Activities 5 and 6 were noted to be automatically obstructed. Hence, the entire process was unwittingly delayed.

\subsection{Mayoral power to make decisions is limited}

The Local Governance and Community Development Program (2017) provides the mayor with executive powers to (a) formulate local public policies via municipal council, (b) frame 
Thaneshwar Bhusal | ASEAN Journal of Community Engagement | Volume 4, Number 2, 2020

policy implementation strategies as the chief of the municipality, and (c) ensure effective implementation of local public policies and annual budget through the utilization of the administrative apparatuses. It seems that the mayor is empowered with dual roles: the chief of the municipal council where legislative decisions is made and chief of the executive board where policy implementation happens. These roles often overlap and even contradict each other, which may result in controversy for the mayor.

From the outset, mayoral power seems to be strong, at least in legislative terms. All the elected members of municipal councils and the board are supposed to follow him/her to implement the list of functions articulated in the Constitution. However, the practice in the last 3 years does not support the argument that mayors are the most powerful political leaders in local governments. The evidence generated for this research shows that the main source of mayoral power stems from the political composition of municipalities, regardless of how beautifully the list of mayoral powers is inscribed in the prevailing local government act.

This signals that successful municipalities were able to bring in their annual budgets due, in part, to their mayors' favourable political atmosphere. In some circumstances, mayors were reported to have used their own strong political backgrounds to handle contrasting ideas, which otherwise could have potentially delayed the budget approval process. In others, with mayors in weak political positions, the opposition politicians were observed to gerrymander the local political landscape. In both scenarios, citizen engagement in the making of annual policymaking and budgeting was adversely affected.

\subsection{Institutional readiness is limited}

The institution of participatory budgeting in Nepal has been evolving for over three decades. It ebbs and flows with the political tide, which has helped refine it in a way that allows ordinary people of diverse social backgrounds to help local officials explore, develop, and prioritize competent policy preferences. The available studies on this noble institution offer insights into how it has suffered as a mere administrative process and grown to a respectable democratic platform at the grassroots level (Adhikari, 2006; Pandeya \& Shrestha, 2016). Interview materials developed for this research confirm that the local annual participatory policymaking and budget process is now able to balance political power between competing political actors and ordinary citizens.

The vacuum at the local government level for over 15 years (2002-2016) provides a unique opportunity to scrutinize the institutional readiness of the participatory policymaking and 
budgetary process in Nepal. As Bhusal (2018) expounds, all the local governments in Nepal were run by appointed bureaucrats because the then-central government could not organize local elections. The initial participatory policymaking and budgetary process was not designed to be run by appointed bureaucrats, yet it was later adapted to be governed within the local bureaucratic jurisdictions. Consequently, citizens of diverse identities, skills, and interests continued to participate in all three stages of the annual policymaking and budgeting process. This timeframe suggests that local governance in Nepal has been historically adaptive to coping with unforeseen crises.

Despite its relatively successful strategic value in dealing with unforeseen political challenges, we do not have any plausible argument to claim that the annual policymaking and budgetary process has proved adaptive to the effects of the COVID-19 pandemic. New norms of social distancing and lockdowns have severely impacted the way citizens participate in all the deliberative forums of the annual budgetary process. However, there have not appeared any alternative routes for them to interact with municipal officials. New innovative methodsincluding online modes-of political and policy communications were not evident in any municipality where this research was conducted.

\subsection{New norms of social distancing and lockdowns caused adverse effects on community consultations}

It is quite paradoxical to note that, on the one hand, all the local governments were under enormous pressure to meet the annual policymaking and budgetary deadline of the second week of July 2020. All the desk works, such as reviewing the policy guidelines and drawing macroeconomic frameworks, were practically possible during the lockdowns. However, almost all the consultative workshops in neighbourhoods and deliberative forums in wards were, on the other hand, severely hampered. The nationwide lockdown which began on the March 24, 2020 left no exceptions for local governments in Nepal to host such forums where ordinary people of different types, interests and capacities would participate in the annual policymaking and budgetary processes.

The analysis further shows that many elected leaders had taken lockdowns as pretext to dodge community engagement in the making of annual local public policies and budgets. What is particularly striking is that even the successful municipalities were found to ignore the value of citizen participation in local policymaking processes. They were not visible in offering alternative means of citizen engagement in their local annual policymaking and budgetary 
Thaneshwar Bhusal | ASEAN Journal of Community Engagement | Volume 4, Number 2, 2020

process. Despite unprecedented power and resources granted to municipalities by the new federalist constitution, no citizen or citizen's group was sufficiently empowered to advocate for alternative approaches to annual policymaking and budgetary processes with the aim of attracting public input.

From participatory governance perspectives, these facts are certainly frustrating. Nonetheless, we should recognize that many successful municipalities, as informed by a highranked official of a municipality, "endeavoured-though informally and of course in nonparticipatory manner - to acquire advice from a range of individuals, including professionals of the provincial finance ministries and sectoral ministries of the federal government." This official claim signals that the prevalence of the Covid-19 pandemic obliged municipal officials to seek "expert advice" in spite of exploring for "ordinary people's views." The articulation of expert advice in the local policymaking and budgetary process might have contributed to enrich the quality of annual policies and budgets but the pandemic must have been responsible for snatching people's democratic right to influence local officials.

\subsection{No online platforms were introduced as alternative ways of citizen engagement}

The nationwide lockdowns imposed in all municipalities certainly call for high quality digital platforms. These platforms were expected to be developed or enhanced by individual municipalities who would simultaneously make sure to inter alia raise the level of digital literacy, expand the availability of digital infrastructure and uphold the viability of the associated cost. Municipal officials needed excellent skills to understand the atmosphere in which digital governance needs to operate. Ordinary people needed adequate access to and facilitation of the use of information and communication technologies. These expectations were found to be absent in almost all the municipalities in Nepal. In other words, no municipalities were found to be operationalizing the use of digital platforms to offer ordinary people the opportunity to have their say in the annual policy and budgetary processes.

Following the introduction of the federalist constitution in 2015, local governments have been provisioned to enjoy unprecedented scale of power, resources, and responsibilities to manage their local affairs. A range of institutions and processes have been devised, most of which are entirely new. Evidence generated for this research shows that many participatory processes are designed to include ordinary people, yet elites' influence continues to prevail in almost all the stages of the decision-making. Additionally, the design of local participatory governance does not envision online participation. Hence, many efforts to introduce e- 
Thaneshwar Bhusal | ASEAN Journal of Community Engagement | Volume 4, Number 2, 2020

governance have either been unused or not properly recognized in the relevant legislation. Both political and administrative leaders at the local level, therefore, fear to rely upon online jurisdictions.

Digital literacy and upgrading of the digital infrastructure are two key elements to fostering citizen engagement during this period of COVID-19 crisis. In the absence of appropriate policy focus and adequate funding, the state of digital literacy in Nepal is very low (Radovanović et al., 2020). A raw assessment of previous years' budgets in many municipalities in Nepal suggests that persistent design flaws have continually failed to provide digital literacy programs to ordinary people. The actual beneficiaries of such programs, if there were any, were not ordinary people who would need to actively participate in municipal decision-making processes. Instead, school-aged children, civil society activists, and NGOs were some dominant groups who were found to have grabbed such opportunities. The investment on digital infrastructure has been frustratingly low in almost all municipalities. Nevertheless, some exceptions appeared. Many municipalities were found to have invested huge amounts of money on ensuring the use of a standardized financial management information system.

\subsection{Information sharing via local televisions, radios, and social media helped a little}

Several information sharing activities were spotted, many of which were visualized in local televisions and official social media platforms. FM radios were given a few advertisements by municipalities to spread the message of the ongoing annual policymaking and budgetary processes. Citizens were offered to provide their views on proposed local public policies and annual budget to municipal officials through these media campaigns. The question, however, is how effective such advertisements were, and to what extent ordinary people took advantage of being informed via televisions, radios, and social media.

The public perception about the campaign was found to be somewhat positive. Many individuals who spoke to this researcher opined that information sharing can respect the democratic right of ordinary people. In the absence of effective digital platforms, most respondents attested to the value of having municipal information via local media. An interviewee mentioned, "...The good news is that municipal officials did not lie to their constituencies. They are confined in their office premises but television and radio advertisements on our local policy and budgets suggest they are with us. I regard it as their respect to ordinary citizens." A caveat must be recognized viz. some people believing that 
Thaneshwar Bhusal | ASEAN Journal of Community Engagement | Volume 4, Number 2, 2020

having media campaigns about proposed annual local policies and budgets could also foster greater participation.

\section{Conclusion}

Speaking at a European conference in Brussels on $8^{\text {th }}$ July 2020, the German Chancellor rightly asserted, “... A pandemic should never be used as a pretext to erode democratic principles." The findings of this research hinted at some aspects of such a "pretext," yet no definitive conclusion can be drawn. Furthermore, the research produced evidence that the global pandemic alone did not cause delays to pass annual local government budgets in Nepal. What marks the pandemic year's annual policymaking and budgeting as special is that ordinary people were unreasonably left out of participating in the local decision-making process. Findings suggest that the COVID-19 induced new norms as social distancing and lockdowns played cruel roles in underestimating citizens' democratic right to participate in the local decision-making process. However, pandemic alone should not be blamed for putting citizens on the periphery. The conventional institutional design of the participatory planning process, the political imbalance of mayoral power, and institutional readiness to cope with unforeseen challenges contributed to the limiting of public space for ordinary citizens. The research showed that the introduction of online platforms would have expanded the boundaries of citizen engagement in annual policymaking and budgeting process.

Citizen engagement, as a scholarly phenomenon, appears mostly in the political science literature. This research produced an insight into the political science scholarship that says political actors are always looking for pretexts to undermine citizen's rights to hold officials accountable for their actions or inaction. In the name of emergency, people in power tend to arbitrarily make decisions, often disregarding the fundamental value of citizen participation in that arrangement. The findings of this research also indicate that politicians tend to seek to suspend opportunities for citizens. Consequently, therefore, crises such as the ongoing COVID19 pandemic may cause the downfall of many flourishing democracies. Viewed from Nepal's case of annual participatory policymaking and budgetary process, this article delivered three key messages to the practitioner's domain. First, participatory, and deliberative forums need to be designed in ways that offer, side-by-side, both in-person and online avenues. This would increase the chances for ordinary people to widen and deepen their presence and voices in local policymaking and budgetary processes. Second, local governments must begin to invest in developing and enhancing online platforms in such a way that ordinary people can easily access 
Thaneshwar Bhusal | ASEAN Journal of Community Engagement | Volume 4, Number 2, 2020

the services they need. Investment is also required to provide digital literacy to the public. Third, accountability loopholes must be explored on a regular basis so that decision-makers can never underestimate citizens' right to participate in decision-making processes. Mechanisms such as social auditing, citizen's juries, and public hearings must be organized on a regular basis.

To sum up, the COVID-19 pandemic has taught us several lessons on the values of citizen engagement in local policymaking and budgets. This research grew from a desire to explore why ordinary citizens were abandoned from participating in the making of local public policies and annual budgets in Nepal. While it endeavoured to deeply understand the underlying institutional and procedural factors of a local-level citizen engagement program in a time of crisis, future research should focus on exploring the broader public policy message of the COVID-19 in the decision-making processes of local governments.

\section{References}

Acharya, K. K., \& Zafarullah, H. (2020). Institutionalising federalism in Nepal: operationalising obstacles, procrastinated progress. Public Administration and Policy: An Asia-Pacific Journal, 23(2), 125-139. https://doi.org/10.1108/PAP-03-2020-0013

Adhikari, D. (2006). Towards Local Democracy in Nepal: Power and Participation in District Development Planning. (PhD Dissertation). Germany: University of Dortmund.

Agbesi, S. (2020). Examining voters' intention to use internet voting system: a case of Ghana. International Journal of Electronic Governance, 12(1), 57-75.

https://doi.org/10.1504/IJEG.2020.106997

Bhusal, T. (2018). Examining citizen participation in local policymaking: an analysis of Nepal's participatory planning process, 2002-2016. (Doctor of Philosophy in Political Science and Policy Studies Original Research). Canberra: University of Canberra.

Bhusal, T. (2019). "Do Informal Forums Matter? Lessons from Nepal's Local Policymaking." The International Journal of Community and Social Development, 1(4), https://doi.org/10.1177/2516602619896187

Bhusal, T., \& Pandeya, G.P. (2021). “Ordinary people's participation in local development planning in Nepal." Development in Practice (forthcoming). 
Thaneshwar Bhusal | ASEAN Journal of Community Engagement | Volume 4, Number 2, 2020

Boin, A., Brock, K., Craft, J., Halligan, J., 't Hart, P., Roy, J., ... \& Turnbull, L. (2020). Beyond COVID19: Five commentaries on expert knowledge, executive action, and accountability in governance and public administration. Canadian Public Administration, 63(3), 339-368. https://doi.org/10.1111/capa.12386

Boin, A., Stern, E., \& Sundelius, B. (2016). The politics of crisis management: Public leadership under pressure. UK: Cambridge University Press.

Byrne, S., \& Shrestha, G. (2014). A compromising consensus? Legitimising local government in post-conflict Nepal. International Development Planning Review, 36(4), 435-454.

https://doi.org/10.3828/idpr.2014.24

Campbell, D. T., \& Yin, R. K. (2018). Case study research and applications: design and methods (sixth ed.). Los Angeles: SAGE Publications.

Capano, G., Howlett, M., Jarvis, D. S. L., Ramesh, M., \& Goyal, N. (2020). Mobilizing Policy (In)Capacity to Fight COVID-19: Understanding Variations in State Responses. Policy and Society, 39(3), 285-308. https://doi.org/10.1080/14494035.2020.1787628

Curato, N., Sass, J., Ercan, S., \& Neymer, S. (2020). Deliberative democracy in the age of serial crisis. International Political Science Review, 41(4).

https://doi.org/10.1177\%2F0192512120941882

Elstub, S. (2018). Deliberative and Participatory Democracy. In A. Bachtiger, J. S. Dryzek, J. Mansbdirge, \& M. E. Warren (Eds.), The Oxford Handbook of Deliberative Democracy (pp. 186). London: Oxford University Press.

Gilman, H. R., \& Peixoto, T. C. (2019). Handbook of Democratic Innovation and Governance. In O. Escobar \& S. Elstub (Eds.), Digital participation. Cheltenham, UK: Edward Elgar Publishing.

Government of Nepal. (2007). The Interim Constitution of Nepal, 2007. Kathmandu: Nepal Law Commission.

Government of Nepal. (2015). The Constitution of Nepal. Kathmandu: Nepal Law Commission.

Government of Nepal. (2017). Local Government Act 2017. Kathmandu: Nepal Law Commission. Haligan, J. (2020). Australia's Response to the Covid-19 Pandemic. In P. Joyce, Fabienne. M, \& P. S. Reddy (Eds), Good Public Governance in a Global Pandemic, (pp 233-243). Brussels: IIAS-IISA.

Halupka, M. (2014). Clicktivism: A Systematic Heuristic. Policy \& Internet, 6(2), 115-132. https://doi.org/10.1002/1944-2866.Poi355 
Heller, P., \& Rao, V. (Eds.). (2015). Deliberation and Development: Rethinking the Role of Voice and Collective in Unequal Societies. Washington D.C.: The World Bank Group.

Khadka, N. (1986). Crisis in Nepal's Partyless Panchayat System: The Case for More Democracy. Pacific Affairs, 59(3), 429-454. https://doi.org/10.2307/2758328

Ministry of Federal Affairs and General Administration. (2017). Planning and Budgeting Guidelines for Local Governments (Ministry of Federal Affairs and General Administration Ed. 2nd ed.). Kathmandu: Ministry of Federal Affairs and General Administration.

Ministry of Federal Affairs and General Administration. (2020, November 21). Updated list: Local governments' annual budget (2077/078). https://mofaga.gov.np/lgbudget

Ministry of Local Development. (2003). Report of High Level Local Bodies Strengthening Committee [unpublished]. Ministry of Local Development, Kathmandu, Nepal.

Moon, M. J. (2020). Fighting Against COVID-19 with Agility, Transparency, and Participation: Wicked Policy Problems and New Governance Challenges. Public Administration Review, 80(4), 651-656. https://doi.org/10.1111/puar.13214

Murphy, J. W., Callaghan, K. A., \& Longino, C. F. (1995). The democratization of service delivery. Early Child Development and Care, 106(1), 19-26.

https://doi.org/10.1080/0300443951060103

National Planning Commission. (2018). Local Level Planning Formulation Guidelines. Kathmandu: National Planning Commission.

Pandeya, G. P., \& Oyama, T. (2019). Revitalizing Local Government Performance Management: Further Dissecting the Role of Socioeconomic Status and Social Mobilization Policy. Local Government Studies, 45(6), 869-892.

\section{https://doi.org/10.1080/03003930.2019.1585817}

Pandeya, G. P., \& Shrestha, S. K. (2016). Does Citizen Participation Improve Local Planning? An Empirical Analysis of Stakeholders' Perceptions in Nepal. Journal of South Asian Development, 11(3), 276-304. https://doi.org/10.1177\%2F0973174116667097

Radovanović, D., Holst, C., Belur, S. B., Srivastava, R., Houngbonon, G. V., Le Quentrec, E., ... \& Noll, J. (2020). Digital Literacy Key Performance Indicators for Sustainable Development. 2020, 8(2), 17. https://doi.org/10.17645/si.v8i2.2587

The Local Governance and Community Development Program. (2017). Annual Progress Report. http://lgcdp.gov.np/ 
Thaneshwar Bhusal | ASEAN Journal of Community Engagement | Volume 4, Number 2, 2020

Waheduzzaman, W., \& As-Saber, S. (2015). Politics and Policy in Achieving Participatory Governance in a Developing Country Context. Politics \& Policy, 43(4), 474-501.

https://doi.org/10.1111/polp.12121

Yasay, D. (2018). Civil society participation as a building block of good governance: The Cagayan de Oro City, Philippines experience. ASEAN Journal of Community Engagement, 2(1). https://doi.org/10.7454/ajce.v2i1.73

Yeni, Y., Najmah, N., \& Davies, S. G. (2020). Predicitive modeling, empowering women, and COVID-19 in South Sumatra, Indonesia. ASEAN Journal of Community Engagement, 4(1). https://doi.org/10.7454/ajce.v4i1.1094 